\title{
PENERAPAN MODEL TALKING STICK UNTUK MENINGKATKAN AKTIVITAS DAN HASIL BELAJAR SISWA KELAS V SDN RANDUAGUNG 02 PADA MATERI PERSIAPAN KEMERDEKAAN INDONESIA
}

\author{
Ety Sudyastuti \\ Sekolah Dasar Negeri 1 Randuagung \\ Singosari, Malang \\ E-mail : ety.randuagung@gmail.com
}

\begin{abstract}
The aim of study was to describe the application of Talking Stick model, student activity when applied Talking Stick model, and student learning result after applied Talking Stick model. This study uses a classroom action research design (PTK) with two cycles and each cycle has two meetings. The data were collected by observation techniques and field notes. The data collection instrument uses observation and test sheets. The collected data is analyzed descriptively qualitative and quantitative. The results showed that the application of Talking Stick model can improve student activity and learning outcomes in learning IPS material Preparation of Indonesian Independence SDN 1 Randuagung. Class V student learning activity in IPS study increased by $10.1 \%$. The learning outcomes of grade V students in IPS study increased after applied Talking Stick model. Students who have completed learning criteria successively in the first cycle of meeting 1 to cycle II meeting 2 as many as 17 students or $63 \%$, 20 students or $74 \%, 22$ students or $81.4 \%$, and 25 students or $92.5 \%$.
\end{abstract}

Key Words: talking stick; activity; learning outcome; preparation of Indonesia's independence

\begin{abstract}
ABSTRAK
Penelitian ini dilaksanakan dengan tujuan untuk mendeskripsikan penerapan model Talking Stick, aktivitas siswa ketika diterapkan model Talking Stick, dan hasil belajar siswa setelah diterapkan model Talking Stick. Penelitian ini menggunakan rancangan penelitian tindakan kelas (PTK) dengan dua siklus dan masing-masing siklus terdapat dua kali pertemuan. Pengumpulan data dilakukan dengan tehnik observasi dan catatan lapangan. Instrumen pengumpulan data menggunakan lembar observasi dan tes. Data yang terkumpul dianalisis secara deskriptif kualitatif dan kuantitatif. Hasil penelitian menunjukkan bahwa penerapan model Talking Stick dapat meningkatkan aktivitas dan hasil belajar siswa dalam pembelajaran IPS materi Persiapan Kemerdekaan Indonesia SDN 1 Randuagung. Aktivitas belajar siswa kelas V dalam belajar IPS meningkat sebanyak 10,1\%. Hasil belajar siswa kelas V dalam belajar IPS meningkat setelah diterapkan model Talking Stick. Siswa yang mendapat kriteria tuntas belajar berturut-turut pada siklus I pertemuan 1 sampai siklus II pertemuan 2 sebanyak 17 siswa atau $63 \%, 20$ siswa atau 74\%, 22 siswa atau 81,4\%, dan 25 siswa atau 92,5\%.
\end{abstract}

Kata Kunci: talking stick; aktivitas; hasil belajar; persiapan kemerdekaan Indonesia

\section{PENDAHULUAN}

Salah satu mata pelajaran dalam Kurikulum Tingkat Satuan Pendidikan (KTSP) adalah Ilmu Pengetahuan Sosial (IPS). Ilmu Pengetahuan Sosial (IPS) merupakan salah satu mata pelajaran yang di dalamnya memuat materi tentang aspek-aspek kehidupan manusia sehari-hari. Aspek tersebut mengkaji seperangkat peristiwa, fakta, konsep dan generalisasi yang berkaitan dengan isu sosial. Selain itu mata pelajaran IPS juga mengarahkan siswa menjadi warga negara Indonesia yang berkompeten, demokratis dan bertanggung jawab, serta menjadi warga negara yang cinta damai (Permendiknas nomor 22 tahun 2006). Untuk mewujudkan hal tersebut 
diperlukan penguasaan materi IPS dengan baik sejak dini, yaitu dari sekolah dasar (SD). Hal ini bertujuan agar siswa mampu mengembangkan pengetahuan, keterampilan dasar yang berguna bagi dirinya dalam kehidupan sehari-hari, baik yang bersifat pragmatis praktis, menyangkut dunia, diri dan kehidupan siswa sesuai dengan tingkat perkembangan, usia dan kemampuan belajarnya serta lingkungan kehidupannya.

Dalam Permendiknas nomor 22 tahun 2006, tujuan mata pelajaran IPS adalah mengenal konsep-konsep yang berkaitan dengan kehidupan masyarakat dan lingkungannya; memiliki kemampuan dasar untuk berfikir logis dan kritis, rasa ingin tahu dan inkuiri, memecahkan masalah, dan keterampilan dalam kehidupan sosial; memiliki komitmen dan kesadaran terhadap nilai-nilai sosial dan kemanusiaan; dan memiliki kemampuan berkomunikasi, bekerjasama dan berkompetisi dalam masyarakat yang majemuk, di tingkat lokal, nasional dan global.

Berdasarkan muatan tujuan IPS tersebut, mengakibatkan pola dalam pembelajaran IPS berkait erat dengan konteks permasalahan lingkungan masyarakat sekitar siswa, baik sebagai sumber belajar maupun sebagai media dalam pembelajaran IPS. Untuk itu pembelajaran IPS, khususnya di sekolah dasar menuntut adanya kesiapan dan kemauan yang baik dari guru, agar guru benar-benar memiliki peran sebagai informator, dinamisator, motivator dan fasilitator. Hal ini menuntut guru untuk kreatif dalam dalam merancang model-model pembelajaran konsep dasar IPS, sehingga pembelajaran akan lebih menarik dan siswa akan belajar lebih antusias (Sapriya, 2009:140). Pembelajaran yang menempatkan guru sebagai pusat pembelajaran (teacher centered), harus diganti dengan pembelajaran yang menempatkan siswa sebagai pusat pembelajaran (student centered), serta mengutamakan pembelajaran yang sesuai dengan karakteristik siswa, dengan harapan kualitas pembelajaran IPS dapat ditingkatkan.

Namun kenyataan praktek pembelajaran di SDN 01 Randuagung pada pembelajaran IPS di kelas $\mathrm{V}$ guru menyampaikan materi dengan ceramah, kemudian memberi tugas berupa latihan-latihan soal yang berada di LKS Fokus. Meski demikian kondisi kelas tetap tampak tertib. Pada akhir pembelajaran guru melakukan pembahasan dengan memberi kesempatan kepada siswa untuk menjawab soal-soal latihan yang telah diberikan sebelumnya, tetapi tidak ada satupun yang dengan sukarela mengangkat tangan untuk menjawab, siswa mau menjawab setelah guru menunjuk, itupun siwa terlihat terpaksa dalam menjawab dan jawabannyapun tidak sesuai yang diharapkan.

Berdasarkan hasil observasi tersebut diketahui bahwa, pembelajaran yang dilakukan di SDN 01 Randuagung pada mata pelajaran IPS di kelas V masih berpusat pada guru. Hal ini dapat dilihat dari metode yang digunakan yaitu ceramah, pemberian tugas dan drill latihanlatihan soal, disamping itu guru juga hanya menggunakan LKS Fokus yang dianggap sebagai sumber belajar dan tidak menggunakan media. Pembelajaran seperti ini berdampak pada rendahnya aktivitas belajar siswa, hal ini terlihat dari rendahnya kemauan siswa untuk mengerjakan latihan-latihan soal yang diberikan oleh guru.Selain rendahnya aktivitas belajar siswa, rata-rata hasil belajar siswa pun masih terbilang cukup rendah, hal ini dapat dilihat dari hasil ulangan harian siswa yang hanya mencapai nilai rata-rata 63, padahal Kriteria Ketuntasan Minimal (KKM) yang ditentukan oleh sekolah adalah 65.

Rendahnya aktivitas dan hasil belajar siswa tersebut diduga karena guru kurang tepat di dalam memilih cara dan penggunaan model pada pembelajaran IPS. Selama ini pembelajaran yang dilakukan guru kurang menarik minat siswa dan siswa cenderung dipaksa mengerjakan latihan-latihan untuk menuntaskan materi, yang berakibat siswa tidak bersemangat dan malas mengerjakan latihan-latihan soal yang diberikan oleh guru. Untuk mengatasi permasalahan tersebut guru pernah mencoba menggunakan berbagai model pembelajaran seperti: Jigsaw, Team Game Tournament (TGT) dan Snow ball Throwing, namun penerapan model tersebut malah membuat suasana kelas gaduh dan materi pelajaran tidak tuntas. 
Salah satu model yang diduga paling tepat untuk memecahkan masalah tersebut adalah model pembelajaran Talking Stick. Selain itu, unsur permainan dalam talking stick memungkinkan siswa berpartisipasi secara aktif dalam pembelajaran. Model pembelajaran ini mengajak siswa untuk belajar sambil bermain, sehingga mereka tidak akan merasa bosan dan tetap bersemangat dalam pembelajaran, serta suasana kelas akan menyenangkan. Disamping itu unsur permainan adalah strategi yang tepat, dalam membelajarkan siswa usia sekolah dasar. Karena, "dunia anak adalah dunia bermain, bermain adalah suatu kegiatan yang dilakukan anak dengan atau tanpa mempergunakan alat yang menghasilkan pengertian, mengembangkan imajinasi anak dan memberi kesenangan" (Sudono dalam Sutama, 2010:51). Dengan demikian, perlu diadakan penelitian yang bertujuan untuk mengetahui penerapan Talking Stick dalam meningkatkan aktivitas dan hasil belajar siswa kelas V SDN 01 Randuagung pada materi Persiapan Kemerdekaan Indonesia.

\section{METODE PENELITIAN}

Pendekatan yang digunakan dalam penelitian ini adalah pendekatan kualitatif, sedangkan jenis penelitiannya ialah deskriptif. Rancangan penelitian yang digunakan adalah rancangan penelitian tindakan kelas (PTK). PTK adalah penelitian yang dilakukan oleh guru kelas atau peneliti untuk meningkatkan kualitas proses dan hasil pembelajaran di kelas/di latar penelitian yang dilakukan secara bersiklus. Tujuan dari penelitian ini adalah untuk meningkatkan kualitas pembelajaran baik proses maupun hasilnya.

Penelitian Tindakan Kelas (PTK) memiliki beberapa karakteristik sebagaimana yang dikemukakan oleh Akbar (2010:26) yaitu: a) Masalahnya berasal dari latar/kelas tempat penelitian dilakukan; b) proses pemecahan masalah tersebut dilakukan secara bersiklus; c) tujuannya untuk memecahkan masalah pembelajaran di kelas, atau meningkatkan kualitas pembelajaran di kelas. Penelitian Tindakan Kelas ini menggunakan model kolaboratif, yaitu kerjasama antara peneliti dengan praktisi di lapangan (guru kelas yang membantu) sebagai kolaborator. Sehingga peneliti dan guru terlibat langsung mulai dari tahap perencanaan tindakan, pelaksanaan, observasi, dan refleksi.

Penelitian dilakukan di kelas V SDN 01 Randuagung yang terletak di Kecamatan Singosari Kabupaten Malang, pada mata pelajaran IPS semester 2 tahun ajaran 2017/2018, pada materi Persiapan Kemerdekaan Indonesia. Subyek penelitian ini adalah siswa kelas V SDN 01 Randuagung dengan jumlah 27 siswa, terdiri atas 18 siswa laki-laki dan 9 siswa perempuan.Model pelaksanaan PTK ini menggunakan acuan model siklus PTK yang dikembangkan oleh Kemmis dan McTaggart (dalam Akbar, 2010:28). Adapun alur atau langkah pelaksanaan tindakan yang dimaksud dapat digambarkan sebagai berikut:

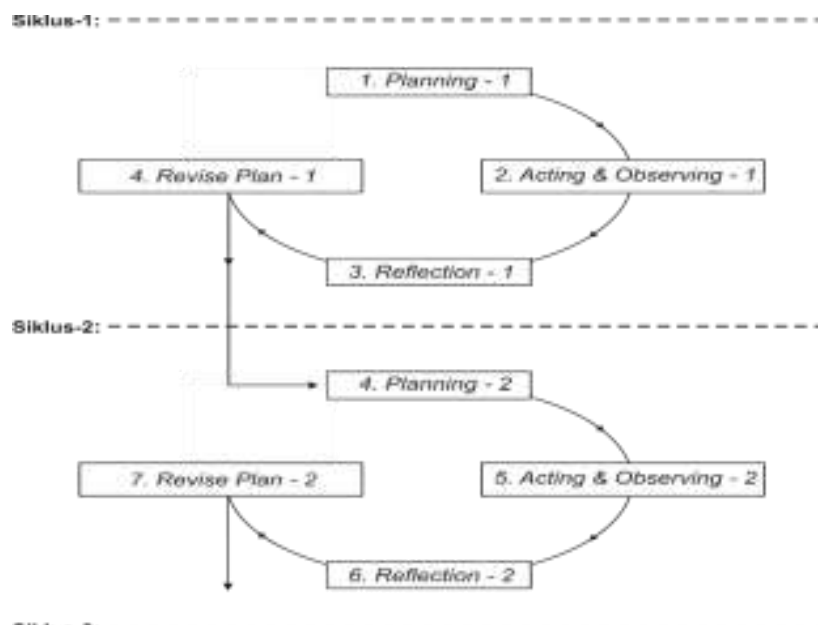

Gambar 1. Siklus PTK menurut Kemmis dan McTaggart (dalam Akbar, 2010:28) 
Pada model siklus di atas tampak bahwa pada setiap siklus terdiri atas: Perencanaan (planning), tindakan dan pengamatan (acting \& Observing), dan perefleksian (reflecting) dan perbaikan rencana (revise plan). Dalam penelitian ini kegiatan-kegiatan dalam siklus dapat dipaparkan sebagai berikut:

\section{a. Siklus I}

\section{Perencanaan (Planning) 1}

Dalam tahap ini, peneliti bersama guru pembantu mempersiapkan skenario pembelajaran berupa Rencana Pelaksanaan Pembelajaran (RPP) dengan menggunakan model Talking Stick serta menyusun LKS yang berkaitan dengan materi yang akan dibelajarkan kepada siswa, mempersiapkan lembar evaluasi, mempersiapkan format observasi aktivitas siswa, lembar observasi penyusunan RPP dan lembar observasi pelaksanaan pembelajaran. Serta mempersiapkan media yang akan digunakan dalam pembelajaran.

\section{Tindakan dan Pengamatan (acting \& observing) 1}

Dalam tahap ini, peneliti bertindak sebagai guru melakukan tindakan sesuai Rencana Pelaksanaan Pembelajaran (RPP) yang telah dibuat pada tahap perencanaan, sedangkan guru pembantu bertindak sebagai observer (pengamat). Pengamatan selama pembelajaran dengan menggunakan model Talking Stick dilakukan meliputi pengamatan terhadap pembelajaran dengan menggunakan model Talking Stick, aktivitas siswa selama pembelajaran, dan nilai siswa pada tes di kegiatan akhir pembelajaran. Dalam pengamatan menggunakan instrumen berupa lembar observasi penyusunan RPP, lembar observasi pelaksanaan pembelajaran, lembar observasi aktivitas siswa, kamera untuk mendokumentasikan segala peristiwa yang terjadi, dan soal-soal tes.

\section{Perefleksian (reflection) 1}

Pada tahap ini peneliti melakukan refleksi bersama guru pembantu (pengamat) terhadap pelaksanaan pembelajaran yang telah dilakukan pada tahap pelaksanaan tindakan. Refleksi dilakukan untuk berpikir ulang terhadap kegiatan yang telah dilakukan, kegiatan yang sudah dicapai, kegiatan yang belum dicapai, masalah pembelajaran yang belum dapat terpecahkan serta kesesuaian pembelajaran yang dilakukan dengan model pembelajaran yang direncanakan.

\section{Perbaikan Rencana (revise plan) 1}

Pada tahap ini peneliti mengadakan rencana perbaikan pada hasil refleksi dengan menentukan aktivitas yang akan dilakukan untuk meningkatkan kualitas pembelajaran dan hasil belajar siswa khususnya pada mata pelajaran IPS yang akan dilanjutkan pada siklus II. Dengan mempertimbangkan kelemahan-kelemahan yang terjadi pada kegiatan sebelumnya, maka rencana tindakan selanjutnya perlu disempurnakan lagi agar tindakan yang akan dilaksanakan berikutnya dapat lebih baik.

\section{b. Siklus II}

\section{Perencanaan (Planning) 2}

Pada dasarnya, perencanaan yang harus dilakukan oleh peneliti pada siklus 2 ini sama dengan siklus 1 hanya saja perencanaan pada siklus 2 ini dilakukan setelah mempelajari hasil refleksi tindakan pada siklus I yang digunakan sebagai masukan dalam melakukan tindakan yang lebih efektif pada siklus II. Peneliti bersama guru kelas V mempersiapkan skenario pembelajaran berupa Rencana Pelaksanaan Pembelajaran (RPP) dengan menggunakan model Talking Stick serta menyusun LKS yang berkaitan dengan materi yang akan dibelajarkan kepada siswa, mempersiapkan lembar evaluasi, mempersiapkan format observasi aktivitas siswa, lembar observasi penyusunan RPP dan lembar observasi pelaksanaan pembelajaran. Serta mempersiapkan media yang akan digunakan dalam pembelajaran.

\section{Tindakan dan Pengamatan (acting \& observing) 2}

Dalam tahap ini, peneliti bertindak sebagai guru melakukan tindakan sesuai Rencana Pelaksanaan Pembelajaran (RPP) yang telah dibuat pada tahap perencanaan. Sedangkan guru 
pembantu bertindak sebagai observer (pengamat), terhadap pembelajaran yang dilakukan oleh peneliti. Pengamatan selama pembelajaran dengan menggunakan model Talking Stick dilakukan meliputi pengamatan terhadap pembelajaran dengan menggunakan model Talking Stick, aktivitas siswa selama pembelajaran, dan nilai siswa pada tes di kegiatan akhir pembelajaran. Dalam pengamatan menggunakan instrumen berupa lembar observasi penyusunan RPP, lembar observasi pelaksanaan pembelajaran, lembar observasi aktivitas siswa, kamera untuk mendokumentasikan segala peristiwa yang terjadi, dan soal-soal tes.

\section{Perefleksian (Reflection) 2}

Pada tahap ini peneliti melakukan refleksi bersama guru pembantu (pengamat) terhadap pelaksanaan pembelajaran yang telah dilakukan pada tahap pelaksanaan tindakan. Refleksi yang dilakukan untuk berpikir ulang terhadap kegiatan yang telah dilakukan, kegiatan yang sudah dicapai, kegiatan yang belum dicapai, masalah pembelajaran yang belum dapat terpecahkan. Refleksi pada tahap kedua ini diharapkan menghasilkan temuan-temuan berupa perubahan aktivitas dan hasil belajar siswa yang berkaitan dengan tindakan pada siklus II.

Data yang diharapkan terkumpul dalam penelitian ini adalah data tentang pelaksanaan model pembelajaran Talking Stick, data tentang aktivitas siswa, dan data tentang hasil belajar siswa. Data tentang pelaksanaan model pembelajaran Talking Stick, meliputi Rencana pelaksanaan pembelajaran yang sesuai dengan langkah-langkah penerapan model Talking Stick. Data tentang aktivitas siswa selama pembelajaran meliputi: membaca/mempelajari kembali, menyanyikan lagu, ketepatan jawaban dan mendengarkan/memperhatikan ketika teman menjawab. Data tentang hasil belajar siswa diperoleh melalui hasil evaluasi siswa yang dilakukan pada setiap pertemuan. Teknik pengumpulan data yang akan digunakan dalam penelitian ini terdiri dari observasi, tes, dan catatan lapangan.

Instrumen yang digunakan dalam penelitian ini adalah lembar observasi pelaksanaan pembelajaran model Talking Stick; lembar observasi aktivitas siswa; dan soal tes, kunci jawaban dan penskoran soal tes untuk mengetahui hasil belajar siswa. Analisis data dalam penelitian ini dilakukan secara kuantitatif dan kualitatif. Data kuantitatif diperoleh dengan menghitung rata-rata kemudian diprosentase sedangkan data kualitatif dianalisis secara deskriptif. Dalam pendekatan kualitatif data dianalisis secara terus menerus dengan cara mengelompokkan data sesuai dengan permasalahan penelitian. Secara rinci teknik analisis untuk setiap pertanyaan pada rumusan masalah penelitian adalah sebagai berikut:

1. Untuk menjawab rumusan masalah pertama, maka dilakukan penilaian terhadap penyusunan Rencana Pelaksanaan Pembelajaran (RPP) menggunakan lembar observasi Alat Penilaian Kemampuan Guru (APKG 1) yang disesuaikan dengan model Talking Stick. Sedangkan aktivitas guru ketika menerapkan model Talking Stick diobservasi menggunakan lembar Alat Penilaian Kemampuan Guru (APKG 2) yang disesuaikan dengan model Talking Stick. Perolehan nilai dari lembar observasi tersebut dihitung menggunakan rumus sebagai berikut :

NA $=\frac{\text { Skor perolehan }}{\text { Skor maksimal }}$

Tabel 1. Kategori Penilaian APKG 1 dan 2

\begin{tabular}{cc}
\hline Nilai & Taraf Keberhasilan \\
\hline $76-100$ & Sangat baik \\
$51-75$ & Baik \\
$26-50$ & Cukup \\
$1-25$ & Kurang \\
\hline
\end{tabular}

Sumber: Arikunto (2003:245) 
2. Untuk menjawab rumusan masalah kedua, maka dilakukan observasi aktivitas siswa melalui lembar observasi aktivitas siswa pada saat melaksanakan Talking Stick. Data tentang aktivitas belajar siswa dihitung menggunakan rumus:

$$
\begin{array}{cl}
\bar{X}=\frac{\sum X}{\sum N} & \\
\text { Keterangan }: & \bar{X}=\text { Nilai rata-rata } \\
\Sigma \mathrm{X} & =\text { Jumlah nilai semua aspek } \\
\Sigma \mathrm{N} & =\text { Jumlah Aspek } \\
& \text { Tabel 2. Kategori Penilaian Aktivitas Belajar Siswa }
\end{array}
$$

\begin{tabular}{cc}
\hline Skor Interval & Kategori \\
\hline $67-100$ & Baik sekali \\
$34-66$ & Baik \\
$1-33$ & Cukup \\
\hline
\end{tabular}

3. Untuk menjawab rumusan masalah ketiga, maka digunakan lembar evaluasi siswa. Pada pra tindakan dilakukan 1 kali tes digunakan untuk mengetahui kemampuan awal siswa. Pada siklus I dan siklus II akan dilakukan masing-masing 2 kali tes. Nilai maksimal yang dapat diperoleh siswa adalah 100. Skor tes klasikal dapat dihitung dengan menggunakan rumus:

$$
\bar{X}=\frac{\sum x}{N}
$$

Keterangan: $\quad \bar{X} \quad=$ Nilai rata-rata

$$
\begin{aligned}
\sum x & =\text { Jumlah skor keseluruhan } \\
N & =\text { Jumlah siswa (Arikunto, 2003:264) }
\end{aligned}
$$

Sedangkan untuk mengiterpretasikan dalam prosentase menggunakan rumus:

$$
P=\frac{F}{N} x 100 \%
$$

Keterangan: $\quad \mathrm{P}=$ prosentase

$\mathrm{F}=$ frekwensi/skor mentah yang dicari prosentasenya

$\mathrm{N}=$ Jumlah frekwensi (Sudijono, 2008:43)

Hasil prosentase yang diperoleh dari perhitungan tersebut kemudian ditetapkan kriterianya. Dalam hal ini kriteria kategori skor siswa dapat dilihat pada tabel berikut:

Tabel 3. Standar Kualitas Pencapaian Keberhasilan

\begin{tabular}{cc}
\hline Presentase & Tingkat keberhasilan \\
\hline $76 \%-100 \%$ & Sangat baik \\
$51 \%-75 \%$ & Baik \\
$26 \%-50 \%$ & Cukup \\
$1 \%-25 \%$ & Kurang \\
\hline \multicolumn{2}{c}{ Sumber: Arikunto (2003:245) }
\end{tabular}

Dari data skor pra tindakan dan post-tes dirata-rata kemudian dibandingkan. Hal ini untuk melihat apakah model pembelajaran Talking Stick dapat meningkatkan hasil belajar siswa. 


\section{HASIL PENELITIAN DAN PEMBAHASAN}

\section{A. Hasil Penelitian}

\section{Hasil Siklus I}

Siklus I terdiri dari 2 pertemuan yaitu pada tanggal : 11 dan 12 Februari 2018, berdasarkan pembelajaran dari dua pertemuan tersebut diperoleh hasil yang akan dijabarkan sebagai berikut:

\section{a. Paparan Data dan Analisis Siklus I}

Berikut akan disajikan tabel perolehan data pada siklus I pertemuan 1 dan 2 beserta analisisnya.

\section{1) Deskripsi Penerapan Model Talking Stick}

Deskripsi penerapan model talking stick pada siklus I dapat diamati pada hasil penilaian APKG 1 dan APKG 2. Berikut penjabarannya.

Tabel 4. Hasil Penilaian APKG 1 Siklus 1

\begin{tabular}{|c|c|c|c|}
\hline \multirow{2}{*}{ No } & \multirow{2}{*}{ Aspek yang dinilai } & \multicolumn{2}{|c|}{ Skor } \\
\hline & & Pert. 1 & Pert. 2 \\
\hline 1 & Kelengkapan Identitas dan kompetensi & 3 & 3 \\
\hline 2 & Menuliskan kompetensi. & 4 & 4 \\
\hline 3 & Menentukan kegiatan membuka pelajaran & 4 & 4 \\
\hline 4 & $\begin{array}{l}\text { Menuliskan langkah-langkah Talking Stick, } \\
\text { Tahap membimbing siswa dalam belajar }\end{array}$ & 4 & 4 \\
\hline 5 & $\begin{array}{l}\text { Menuliskan langkah-langkah Talking Stick, } \\
\text { Tahap memandu pelaksanaan Talking Stick }\end{array}$ & 4 & 4 \\
\hline 6 & Menentu kan alokasi waktu pembelajaran & 3 & 3 \\
\hline 7 & $\begin{array}{c}\text { Menentukan prosedur (awal, proses, akhir) dan jenis penilaian } \\
\text { (lisan, tertulis, perbuatan) }\end{array}$ & 3 & 4 \\
\hline 8 & Membuat alat penilaian dan kunci jawaban & 3 & 4 \\
\hline & Nilai Akhir & 87,5 & 93,7 \\
\hline & Rata-rata & \multicolumn{2}{|c|}{90,6} \\
\hline
\end{tabular}

Tabel 5. Hasil Penilaian APKG 2 Siklus 1

\begin{tabular}{lccc}
\hline \multirow{2}{*}{ No } & \multirow{2}{*}{ Aspek yang dinilai } & \multicolumn{2}{c}{ Skor } \\
\cline { 3 - 4 } & Pra kegiatan dan Apersepsi & 4 & Pert. 2 \\
\hline 1 & Membimbing siswa dalam belajar & 4 & 5 \\
2 & Memandu pelaksanaan Talking Stick & 5 & 5 \\
3 & Kesimpulan, refleksi dan evaluasi & 5 & 4 \\
4 & Nilai Akhir & 90 & 90 \\
\hline & Rata-rata & & 90 \\
\hline
\end{tabular}

Berdasarkan Tabel 4 dan 5 mengenai kegiatan penerapan model Talking Stick dengan menggunakan penilaian kemampuan guru (APKG) yang telah disesuaikan dengan model, diperoleh data bahwa pada pertemuan 1 APKG 1 dan APKG 2 memperoleh nilai 87,5 dan 93,7. Sedangkan pada pertemuan 2 APKG 1 dan APKG 2 menunjukkan nilai 90 dan 90. Berdasarkan tabel APKG 1 pertemuan 1 dan 2 diperoleh nilai rata-rata 90,6. Sedangkan APKG 2 pertemuan 1 dan 2 diperoleh rata-rata 90. 


\section{2) Deskripsi Peningkatan Aktivitas Belajar Siswa}

Tabel 6. Observasi Aktivitas Siswa Siklus I

\begin{tabular}{cccc}
\hline \multirow{2}{*}{ No } & \multirow{2}{*}{ Aspek yang dinilai } & \multicolumn{2}{c}{ Skor } \\
\cline { 3 - 4 } & & Pertemuan 1 & Pertemuan 2 \\
\hline 1 & Membaca/mempelajari kembali hasil pembahasan LKS & 63,6 & 69,6 \\
2 & Menyanyikan lagu & 59 & 68,1 \\
3 & Tertib saat memindah tongkat & 59 & 72,7 \\
4 & Ketepatan jawaban & 66,6 & 71,2 \\
5 & Mendengarkan/memperhatikan ketika teman menjawab & 59 & 59 \\
\hline & Rata-rata aktivitas belajar siswa & 61,4 & 68,1 \\
\hline & Rata-rata aktivitas belajar siswa siklus I & \multicolumn{3}{c}{64,8} \\
\hline
\end{tabular}

Berdasarkan Tabel 6, dapat dilihat bahwa nilai rata-rata aktivitas siswa pada pertemuan 1 siklus I adalah 61,4. Pada pertemuan 2 terjadi peningkatan aktivitas siswa menjadi 68,1. Peningkatan aktivitas belajar siswa sebanyak 6,7.

3) Deskripsi Peningkatan Hasil Belajar Siswa

Pada siklus I peningkatan hasil belajar siswa dalam menyelesaikan soal dalam bentuk tes tulis dapat dijelaskan pada tabel di bawah ini:

Tabel 7. Hasil Belajar Siswa Siklus I

\begin{tabular}{|c|c|c|c|c|c|}
\hline \multirow{2}{*}{ NO } & \multirow{2}{*}{ NAMA SISWA } & \multicolumn{2}{|c|}{$\begin{array}{l}\text { SIKLUS I } \\
\end{array}$} & \multirow{2}{*}{ RATA-RATA } & \multirow{2}{*}{ KETERANGAN } \\
\hline & & PERT. 1 & PERT. 2 & & \\
\hline 1 & Siswa 1 & 59 & 58 & 58 & Belum Tuntas \\
\hline 2 & Siswa 2 & 48 & 58 & 53 & Belum Tuntas \\
\hline 3 & Siswa 3 & 48 & 69 & 59 & Belum Tuntas \\
\hline 4 & Siswa 4 & 85 & 81 & 83 & Tuntas \\
\hline 5 & Siswa 5 & 81 & 65 & 73 & Tuntas \\
\hline 6 & Siswa 6 & 67 & 73 & 70 & Tuntas \\
\hline 7 & Siswa 7 & 52 & 65 & 59 & Belum Tuntas \\
\hline 8 & Siswa 8 & 70 & 77 & 74 & Tuntas \\
\hline 9 & Siswa 9 & 62 & 62 & 62 & Belum Tuntas \\
\hline 10 & Siswa 10 & 81 & 88 & 85 & Tuntas \\
\hline 11 & Siswa 11 & 70 & 77 & 74 & Tuntas \\
\hline 12 & Siswa 12 & 81 & 88 & 85 & Tuntas \\
\hline 13 & Siswa 13 & 74 & 88 & 81 & Tuntas \\
\hline 14 & Siswa 14 & 59 & 77 & 68 & Tuntas \\
\hline 15 & Siswa 15 & 67 & 62 & 64 & Belum Tuntas \\
\hline 16 & Siswa 16 & 78 & 92 & 85 & Tuntas \\
\hline 17 & Siswa 17 & 74 & 88 & 81 & Tuntas \\
\hline 18 & Siswa 18 & 81 & 96 & 89 & Tuntas \\
\hline 19 & Siswa 19 & 67 & 81 & 74 & Tuntas \\
\hline 20 & Siswa 20 & 52 & 54 & 53 & Belum Tuntas \\
\hline 21 & Siswa 21 & 67 & 54 & 60 & Belum Tuntas \\
\hline 22 & Siswa 22 & 74 & 70 & 72 & Tuntas \\
\hline 23 & Siswa 23 & 59 & 58 & 59 & Belum Tuntas \\
\hline 24 & Siswa 24 & 67 & 67 & 67 & Tuntas \\
\hline 25 & Siswa 25 & 59 & 67 & 63 & Belum Tuntas \\
\hline 26 & Siswa 26 & 62 & 70 & 66 & Tuntas \\
\hline 27 & Siswa 27 & 74 & 70 & 72 & Tuntas \\
\hline & Jumlah & 1818.6 & 1954.7 & 1886.7 & \\
\hline & Rata-rata & 67.4 & 72.4 & 69.9 & \\
\hline
\end{tabular}


Berdasarkan Tabel 7, diperoleh data bahwa rata-rata hasil belajar siswa pada siklus I adalah 69,9. Jumlah siswa yang telah mencapai standar ketuntasan belajar adalah 17 siswa, sedangkan yang belum mencapai standar ketuntasan belajar sebanyak 10 siswa.

\section{b. Refleksi dan Kesimpulan Siklus I}

Setelah melakukan pertemuan 1 dan 2 dapat diperoleh data tentang penggunaan model Talking Stick dalam pembelajaran IPS di kelas V yang ditinjau dari penerapannya, aktivitas belajar siswa dan hasil belajar. Berikut dikemukakan hasil refleksi pelaksanaan siklus I:

1. Pelaksanaan pembelajaran menggunakan model Talking Stick sudah baik, namun masih belum didapatkan hasil yang optimal. Sehingga perlu dilakukan perbaikan-perbaikan pada siklus II.

2. Guru sudah merencanakan RPP dengan baik dan sudah menampakkan semua indikator dalam pelaksanaan pembelajaran, namun dalam pelaksanaanya membutuhkan waktu yang lebih lama dari yang direncanakan dalam RPP

3. Sebagian besar siswa sulit memahami maksud dari petanyaan yang terdapat dalam LKS.

4. Berdasarkan hasil observasi, sebagian besar aktivitas belajar siswa masih harus disuruh oleh guru, sehingga masih perlu ditingkatkan.

5. Hasil belajar siswa menunjukkan peningkatan yang signifikan, dengan nilai rata-rata mencapai 71,6, namun ada 7 siswa yang belum mencapai standar ketuntasan belajar minimal, sehingga maih perlu ditingkatkan pada siklus II.

\section{c. Upaya perbaikan untuk siklus II}

Berikut ini terdapat beberapa hal yang direncanakan untuk diperbaiki pada siklus II:

1. Mengembangkan indikator sesuai dengan alokasi waktu yang direncanakan, menyiapkan media dan sumber belajar serta menata bangku sebelum jam pelajaran dimulai.

2. Menyerderhankan dan memperjelas kalimat dalam LKS

3. Pada saat menjelaskan langkah-langkah talking stick guru menjelaskan bahwa setiap aktivitas dinilai oleh guru, disamping itu pemberian nomor dada untuk masing-masing siswa.

4. Memberikan pengawasan yang intensif untuk siswa yang belum mencapai ketuntasan belajar minimal.

\section{Hasil Siklus II}

a. Paparan Data dan Analisis Siklus II

1) Deskripsi penerapan model Talking Stick

Deskripsi penerapan model Talking Stick dapat diamati pada hasil penilaian APKG 1 dan APKG 2. Berikut penjabarannya.

Tabel 8. Hasil Penilaian APKG 1 Siklus II

\begin{tabular}{lccc}
\hline \multirow{2}{*}{ No } & Aspek yang dinilai & \multicolumn{2}{c}{ Skor } \\
\cline { 3 - 4 } & Pert. 1 & Pert. 2 \\
\hline 1 & Kelengkapan Identitas dan kompetensi & 3 & 3 \\
2 & Menuliskan kompetensi. & 4 & 4 \\
3 & Menentukan kegiatan membuka pelajaran & 4 & 4 \\
4 & Menuliskan langkah-langkah Talking Stick, & 4 & 4 \\
5 & Tahap membimbing siswa dalam belajar & & \\
& Menuliskan langkah-langkah Talking Stick, & 4 & 4 \\
6 & Tahap memandu pelaksanaan Talking Stick & 4 & 4 \\
7 & Menentu kan alokasi waktu pembelajaran & 4 & 4 \\
8 & Menentukan prosedur (awal, proses, akhir) dan jenis & 4 & 4
\end{tabular}




\begin{tabular}{|c|c|c|c|}
\hline \multicolumn{2}{|r|}{ Nilai Akhir } & 96,8 & 96,8 \\
\hline & Rata-rata & \multicolumn{2}{|c|}{96,8} \\
\hline \multicolumn{4}{|c|}{ Tabel 9. Hasil Penilaian APKG 2 Siklus II } \\
\hline \multirow{2}{*}{ No } & \multirow{2}{*}{ Aspek yang dinilai } & \multicolumn{2}{|c|}{ Skor } \\
\hline & & Pert. 1 & Pert. 2 \\
\hline 1 & Pra kegiatan dan Apersepsi & 4 & 4 \\
\hline 2 & Membimbing siswa dalam belajar & 5 & 5 \\
\hline 3 & Memandu pelaksanaan Talking Stick & 5 & 5 \\
\hline 4 & Kesimpulan, refleksi dan evaluasi & 4 & 5 \\
\hline \multicolumn{2}{|r|}{ Nilai Akhir } & 90 & 95 \\
\hline & Rata-rata & \multicolumn{2}{|c|}{92,2} \\
\hline
\end{tabular}

Berdasarkan Tabel 8 dan 9, mengenai kegiatan penerapan model Talking Stick dengan menggunakan lembar penilaian kemampuan guru (APKG) yang telah disesuaikan dengan model, diperoleh data bahwa pada pertemuan 1 APKG 1 dan APKG 2 memperoleh nilai 96,8 dan 90. Sedangkan pada pertemuan 2 APKG 1 dan APKG 2 menunjukkan nilai 96,8 dan 95.

\section{2) Deskripsi Peningkatan Aktivitas Belajar Siswa}

Tabel 10. Observasi Aktivitas Siswa Siklus II

\begin{tabular}{|c|c|c|c|}
\hline \multirow{2}{*}{ No } & \multirow{2}{*}{ Aspek yang dinilai } & \multicolumn{2}{|c|}{ Skor } \\
\hline & & Pertemuan 1 & Pertemuan 2 \\
\hline 1 & Membaca/mempelajari kembali hasil pembahasan LKS & 71,1 & 78,7 \\
\hline 2 & Menyanyikan lagu & 68,1 & 83,3 \\
\hline 3 & Tertib saat memindah tongkat & 75,7 & 78,7 \\
\hline 4 & Ketepatan jawaban & 69,9 & 81,8 \\
\hline 5 & Mendengarkan/memperhatikan ketika teman menjawab & 62,2 & 77,7 \\
\hline & Rata-rata aktivitas belajar siswa & 69,4 & 78,7 \\
\hline & Rata-rata aktivitas belajar siswa siklus II & \multicolumn{2}{|c|}{74,1} \\
\hline
\end{tabular}

Berdasarkan Tabel 10, dapat dilihat bahwa nilai rata-rata aktivitas belajar siswa pada pertemuan 1 siklus II adalah 69,4. Pada pertemuan 2 terjadi peningkatan aktivitas belajar siswa menjadi 78,7. Peningkatan aktivitas belajar siswa sebanyak 9.3. dengan rincian peningkatan aktivitas tiap aspek meliputi: aktivitas membaca atau mempelajari kembali hasil pembahasn LKS dari 71,1 menjadi 78,7, menyanyikan lagu dari 68,1 menjadi 83,3, tertib saat memindah tongkat dari 75,7 menjadi 78,7, ketepatan jawaban dari 69,9 menjadi 81,8 dan mendengarkan atau memperhatikan ketika teman menjawab dari 62,2 menjadi 77,7. Sedangkan rata-rata aktivitas belajar siswa pada siklus II adalah 74,1.

\section{3) Deskripsi Peningkatan Hasil Belajar Siswa}

Pada siklus II peningkatan hasil belajar siswa dalam menyelesaikan soal dalam bentuk tes tulis dapat dijelaskan pada tabel di bawah ini:

Tabel 10. Hasil Belajar Siswa Siklus II

\begin{tabular}{cccccc}
\hline \multirow{2}{*}{ NO } & \multirow{2}{*}{ NAMA SISWA } & \multicolumn{2}{c}{ SIKLUS I } & \multirow{2}{*}{ RATA-RATA } & \multirow{2}{*}{ KETERANGAN } \\
\cline { 3 - 4 } & & PERT. 1 & PERT. 2 & & \\
\hline 1 & Siswa 1 & 47 & 65 & 56 & Belum Tuntas \\
2 & Siswa 2 & 53 & 60 & 57 & Belum Tuntas \\
3 & Siswa 3 & 69 & 75 & 72 & Tuntas \\
4 & Siswa 4 & 83 & 85 & 84 & Tuntas \\
26 & & & & &
\end{tabular}




\begin{tabular}{cccccc}
5 & Siswa 5 & 83 & 90 & 87 & Tuntas \\
6 & Siswa 6 & 67 & 70 & 68 & Tuntas \\
7 & Siswa 7 & 70 & 75 & 73 & Tuntas \\
8 & Siswa 8 & 83 & 70 & 77 & Tuntas \\
9 & Siswa 9 & 67 & 75 & 71 & Tuntas \\
10 & Siswa 10 & 73 & 95 & 84 & Tuntas \\
11 & Siswa 11 & 70 & 85 & 78 & Tuntas \\
12 & Siswa 12 & 87 & 95 & 91 & Tuntas \\
13 & Siswa 13 & 83 & 80 & 82 & Tuntas \\
14 & Siswa 14 & 67 & 85 & 76 & Tuntas \\
15 & Siswa 15 & 73 & 75 & 74 & Tuntas \\
16 & Siswa 16 & 83 & 100 & 92 & Tuntas \\
17 & Siswa 17 & 83 & 95 & 89 & Tuntas \\
18 & Siswa 18 & 90 & 85 & 88 & Tuntas \\
19 & Siswa 19 & 83 & 80 & 82 & Tuntas \\
20 & Siswa 20 & 50 & 65 & 58 & Belum Tuntas \\
21 & Siswa 21 & 67 & 75 & 71 & Tuntas \\
22 & Siswa 22 & 72 & 72 & 72 & Tuntas \\
23 & Siswa 23 & 59 & 59 & 59 & Belum Tuntas \\
24 & Siswa 24 & 67 & 67 & 67 & Tuntas \\
25 & Siswa 25 & 63 & 70 & 67 & Tuntas \\
26 & Siswa 26 & 66 & 66 & 66 & Tuntas \\
27 & Siswa 27 & 74 & 77 & 76 & Tuntas \\
\hline
\end{tabular}

Berdasarkan Tabel 10, diperoleh data bahwa rata-rata hasil belajar siswa pada siklus II adalah 74,4. Jumlah siswa yang telah mencapai standar ketuntasan belajar sebanyak 23 siswa, sedangkan yang belum mencapai standar ketuntasan belajar sebanyak 4 siswa.

\section{b. Refleksi}

Pada bagian refleksi siklus II ini akan dikemukakan beberapa hal tentang hasil proses pelaksanaan pembelajaran antara lain:

1. Pelaksanaan pembelajaran Talking Stick pada siklus II sudah lebih baik dari pada siklus I.

2. Waktu yang direncanakan dalam Rencana Pelakasanaan Pembelajaran (RPP) sudah sesuai dengan waktu pelaksanaannya.

3. Sebagian besar siswa sudah dapat memahami pertanyaan-pertanyaan dalam LKS, sehingga pertanyaan tentang LKS berkurang drastis dan siswa terlihat berkonsentrasi dalam pengerjaan LKS.

4. Pada saat kerja kelompok sebagian besar siswa sudah saling berkerjasama dalam pengerjaan LKS.

5. Berdasarkan hasil observasi aktivitas belajar siswa, aktivitas belajar siswa pada siklus II mengalami peningkatan pesat dibandingkan dengan siklus I.

6. Berdasarkan hasil tes menunjukkan bahwa hasil belajar siswa mengalami peningkatan, meskipun ada 4 anak yang belum mencapai standar ketuntasan belajar minimal.

\section{B. Pembahasan}

\section{Penerapan Model Talking Stick pada Pembelajaran IPS}

Penerapan model Talking Stick pada pembelajaran IPS adalah penerapan suatu model dalam pembelajaran IPS yang dirancang dalam bentuk permainan dengan menggunakan tongkat, yang bertujuan mendorong siswa untuk berani mengungkapkan pendapat. Dengan kata lain model pembelajaran ini mengajak siswa untuk belajar sambil bermain, sehingga tercipta 
kondisi pembelajaran yang menyenangkan. Permainan yang dimaksud disini yaitu setelah siswa diberi kesempatan untuk mempelajari suatu materi tertentu salah satu siswa diberi tongkat dan tongkat tersebut dipindah dari siswa satu ke siswa lainnya dengan diiringi musik atau dengan menyanyikan lagu dan siswa yang memegang tongkat wajib menjawab pertanyaan yang diberikan oleh guru.

Untuk mengetahui penerapan pembelajaran model Talking Stick sudah sesuai dengan langkah-langkah, maka dilakukan penilaian terhadap penyusunan Rencana Pelaksanaan Pembelajaran (RPP) dan penilaian terhadap pelaksanaan pembelajaran yang dilakukan guru selama menerapkan model Talking stick, menggunakan lembar APKG 1 dan APKG 2 yang telah disesuaikan dengan model. Pada siklus II penerapan model Talking Stick pada pembelajaran IPS mengalami peningkatan dari 90,3 pada sikus I menjadi 93,4 pada siklus II atau meningkat sebesar 2,2. Dengan demikian penerapan model Talking Stick pada pembelajaran IPS dari siklus I ke siklus II mengalami peningkatan dan mencapai perolehan nilai dengan Kriteria sangat baik. Peningkatan tersebut dipengaruhi oleh perencanaan yang baik, karena dengan rencana yang baik diharapkan pembelajaran yang akan dilaksanakan juga berjalan dengan baik pula. Hal ini sesuai dengan pendapat Ibrahim dan Nana (2010:30) yang menyatakan bahwa salah satu hal yang memegang peranan penting bagi keberhasilan pembelajaran adalah proses pelaksanaan pembelajaran dan pelaksanaan pembelajaran yang baik sangat dipengaruhi oleh perencaan yang baik pula. Sejalan dengan pendapat tersebut dalam Permendiknas no 41 tentang Sisdiknas juga disebutkan bahwa pembelajaran perlu direncanakan, dilaksanakan dan diawasi agar terlaksana secara efektif dan efisen.

Pada siklus II guru mengembangkan indikator dengan mempertimbangkan waktu pembelajaran, dengan demikian diharapkan semua indikator dapat terealisasi dengan baik pada saat pelaksanaan pembelajaran, Faturrohman (2009:54) "menjelaskan bahwa dalam penyusunan tujuan pembelajaran hendaknya mempertimbangkan apakah waktu yang tersedia cukup untuk mencapai tujuan-tujuan itu". Penataan ruang kelas, penyediaan media dan sumber belajar perlu disiapkan agar pelaksanaan pembelajaran berjalan dengan baik, sejalan dengan hal tersebut di atas Faturrohman (2009:104) menjelaskan bahwa pengelolaan kelas sangat penting dalam pembelajaran, pengelolan kelas merupakan penyediaan fasilitas bagi bermacam-macam kegiatan belajar siswa untuk mencapai tujuan belajar.

Pada siklus II alat bantu belajar siswa yaitu Lembar Kegiatan Siswa (LKS) disusun menggunakan kalimat yang sederhana, sesuai dengan buku sumber yang digunaan siswa dan dilengkapi dengan gambar-gambar. Menurut Piaget (dalam Isjoni 2010:35) secara umum anak SD tahap berpikirnya masih dalam tahap opersional konkret, dimana dalam usia ini anak memandang dunia adalah keseluruhan yang utuh dan anak melakukan sesuatu berdasarkan apa yang mereka lihat. Sementara itu Bruner (dalam Achmad, 2005) menyatkan bahwa dalam pembelajaran IPS materinya penuh dengan pesan-pesan yang bersifat absrak, untuk mengkongkretkan itu dapat dilakukan dengan enactive, iconic, dan symbolic melalui percontohan dengan gerak tubuh, gambar, bagan, peta, grafik, lambang, keterangan lanjut, atau eleborasi dalam kata-kata yang dapat dipahami.

\section{Aktivitas Belajar Siswa pada Pembelajaran IPS dengan Model Talking Stick.}

Pada siklus I nilai rata-rata aktivitas belajar siswa sebesar 64,8, dengan rinciaan nilai rata-rata tiap aspek, yang meliputi: membaca/mempelajari kembali hasil pembasan LKS 66,6, menyanyikan lagu 63,6, tertib memindah tongkat 65,9, ketepatan jawaban 68,9 dan mendengarkan/memperhatikan teman menjawab 59. Sedangkan pada siklus II nilai rata-rata aktivitas belajar siswa 74,7, dengan rincian nilai rata-rata tiap aspek, yang meliputi: membaca/mempelajari kembali hasil pembasan LKS 74,9, menyanyikan lagu 75,7, tertib memindah tongkat 77,2, ketepatan jawaban 75,9 dan mendengarkan/memperhatikan teman menjawab 70. Sehingga dapat disimpulkan bahwa nilai rata-rata aktivitas belajar siswa pada 
siklus II mengalami peningkatan dari 64,8 menjadi 74,7 atau meningkat sebesar 9,9, dengan Kriteria pada siklus I baik dan pada siklus II sangat baik.

Peningkatan tersebut karena sebelum melaksanaka permainan Talking Stick guru menjelaskan langkah-langkah serta aturan-aturan yang harus dilakukan oleh siswa, disamping itu siswa juga diberi tahu bahwa setiap aktivitas dinilai oleh guru, setiap aktivitas yang baik akan mendapatkan penghargaan dan aktivitas yang tidak sesuai dengan aturan yang telah ditetapkan akan mendapat hukuman. Dengan demikian siswa akan terdorong untuk melakukan aktivitas belajar sesuai dengan aturan yang telah ditetapkan, dan aktivitas belajar siswa akan tinggi. Hal ini sejalan dengan hasil penelitian Degeng (dalam Riyanto, 2009:29) yang menyatakan bahwa siswa yang diberi tahu langkah-langkah dan tujuan belajarnya sebelum belajar dimulai, memperlihatkan aktivitas dan hasil belajar yang lebih tinggi dari pada yang tidak. Disamping penguatan berupa pemberian penghargaan dan hukuman akan mendorong siswa dan memotivasi siswa untuk melakukan sesuatu sesuai aturan yang ditetapkan (Sumantri, 2008:2.40).

Pada siklus II pertemuan 2, saat siswa melakukan permainan Talking Stick, guru mengiringi dengan memutarkan lagu melalui Hand Phone. Dengan demikian diharapakan siswa akan lebih bersemangat dalam melakukan permainan Talking Stick. Hal ini sesuai dengan yang diungkapkan Soeprijono (2009:110) bahwa pada saat anak melakukan permainan Talking Stick hendaknya diiringi dengan musik atau lagu, ini dilakukan dengan tujuan agar siswa tidak terlalu tegang dan takut yang berlebihan pada saat melakukan permainan Talking Stick. Musik yang ditata tepat waktu dan situasi dapat membantu menata suasana hati, mengubah keadaan mental dan dapat membantu belajar lebih baik. Musik dapat menghilangkan rasa penat, boring dan dapat membantu rileksasi pada pikiran sehingga dapat melakukan aktivitas dengan baik (Fathurrohman, 2009:111).

\section{Hasil Belajar Siswa dengan Penerapan Model Talking Stick.}

Pada siklus I pertemuan 1 dapat dianalisis siswa yang tuntas belajar sebanyak 17 siswa atau $63 \%$, pada siklus I pertemuan 2 siswa yang tuntas belajar sebanyak 20 siswa atau $74 \%$, pada siklus II pertemuan 1 siswa yang tuntas belajar sebanyak 22 siswa atau 81,4\%, dan pada siklus II pertemuan 2 siswa yang tuntas belajar sebanyak 25 siswa atau 92,5\%. Sedangkan nilai rata-rata hasil belajar siswa pada siklus I dan siklus II mengalami peningkatan dari 71,1 menjadi 76,8 , dengan peningkatan sebesar 5,7.

Terjadinya peningkatan hasil belajar siswa dari siklus I ke siklus II dikarenakan adanya upaya-upaya perbaikan yang dilakukan guru, terhadap kekurangan-kekurangan yang terjadi pada siklus I. pada pelaksanaan siklus II guru memberikan bimbingan lebih terhadap siswa yang pada siklus I belum mencapai ketuntasan belajar hal ini dimaksudkan agar guru mengenali karakteristik siswa sehingga dapat menentukan perlakuan pembelajaran yang tepat bagi siswa yang bersangkutan. Disamping itu pada siklus II utamanya pada pertemuan 2, pada saat melakukan permainan Talking Stick jika pertanyaan yang diajukan guru sesuai LKS sudah habis, maka guru mengulang pertanyaan-pertanyaan tersebut, sampai semua siswa mendapat giliran menjawab. Riyanto (2009:80) menjelaskan bahwa Implikasi prinsip pengulangan bagi guru adalah mampu memulihkan antara kegiatan pembelajaran yang berisi pesan yang membutuhkan pengulangan, salah satunya adalah dengan membuat kegiatan pengulangan yang bervariasi.

Meskipun begitu, pada siklus II masih ada 4 siswa yang belum mencapai ketuntasan belajar yang telah ditentukan. Berdasarkan pengamatan peneliti dan hasil wawancara dengan guru kelas, ketiga siswa tersebut memang memiliki kemampuan belajar yang sangat lamban jika dibandingkan dengan teman-temannya yang lain. Hal tersebut dapat dibuktikan selama penelitian, dalam pembelajaran guru selalu memberikan perhatian khusus dan intensif terhadap 
siswa tersebut, namun dari pertemuan-ke pertemuan hasil belajarnya memang belum mengalami peningkatan yang berarti.

Sedangkan untuk deskripsi perbandingan hasil belajar siswa pra tindakan dengan hasil belajar siswa setelah diterapkannya model Talking Stick dapat dilihat pada tabel 5.4. Hasil belajar siswa kelas V pada mata pelajaran IPS mengalami peningkatan setelah diterapkan model Talking Stick. Berdasarkan Tabel 13, dapat diketahui perbandingan hasil belajar siswa setelah diterapkanya model Talking Stick. Pada pra tindakan siswa yang tuntas belajar sebanyak 10 siswa atau $37 \%$ dan yang belum tuntas belajar sebayak 17 siswa atau 63\%. Sedangkan setelah diterapkan model Talking Stick siswa yang tuntas belajar sebanyak 25 siswa atau 92,5\% dan yang belum tuntas belajar sebanyak 4 siswa atau 14,8\%.

Hasil observasi pada pra tindakan, saat pembelajaran guru menggunakan metode ceramah, pemberian tugas dan drill latihan-latihan soal. Hal tersebut menunjukkan bahwa mengajar dengan menggunakan metode-metode tersebut membuat hasil belajar siswa rendah. Setelah diterapkan model Talking Stick hasil belajar siswa mengalami peningkatan yang cukup signifikan, hal ini disebabkan karena model Talking Stick adalah model pembelajaran kooperatif yang dirancang dalam bentuk permainan dengan menggunakan bantuan tongkat, yang bertujuan mendorong siswa untuk berani mengungkapkan pendapat. Dengan kata lain model pembelajaran ini mengajak siswa untuk belajar sambil bermain, sehingga tercipta kondisi pembelajaran yang menyenangkan. Selain itu suherman (2008) menyebutkan Talking Stick memiliki beberapa kelebihan antara lain: (1) menguji kesiapan siswa, (2) melatih siswa memahami cepat, (3) agar lebih giat belajar, (4) siswa lebih bersemangat mengikuti pelajaran. Kelebihan yang dimiliki model Talking Stick ini merupakan salah satu faktor yang mempengaruhi hasil belajar siswa.

Menurut Syah (2010:129) mengemukakan bahwa ada tiga faktor yang mempengaruhi hasil belajar siswa antara lain: faktor internal, faktor eksternal dan faktor pendekatan belajar. Faktor internal meliputi: faktor psikologis baik yang bersifat bawaan maupun yang diperoleh melalui pengalaman seperti kecerdasan, bakat, sikap, minat, kebiasaan, kebutuhan, motivasi, dan kematangan fisik. Faktor eksternal meliputi lingkungan, budaya, adat istiadat, ilmu pengetahuan dan teknologi serta fasilitas belajar. Faktor pendekatan belajar yaitu jenis upaya belajar siswa yang meliputi strategi dan metode yang digunakan siswa untuk melakukan kegiatan mempelajari materi-materi pelajaran. Dengan demikian dapat disimpulkan bahwa pemilihan strategi dan metode yang tepat akan berdampak pada hasil belajar siswa.

\section{PENUTUP}

Berdasarkan paparan data dan pembahasan terhadap temuan-temuan yang diperoleh dalam penelitian ini, maka dapat dikemukakan beberapa kesimpulan sebagai berikut:

1. Penerapan model Talking Stick pada mata pelajaran IPS siswa kelas V SDN 01 Randuagung dapat meningkatkan pembelajaran materi Persiapan Kemerdekaan Indonesia, baik dari proses pembelajaran, aktivitas siswa, maupun hasil belajar siswa. Penerapan model berturut-turut dari siklus I dan II memperoleh nilai rata-rata 90,3 dan 93,4.

2. Penerapan model Talking Stick dapat meningkatkan aktivitas belajar siswa kelas V SDN 01 Randuagung pada mata pelajaran IPS. Aktivitas belajar siswa pada siklus I dan II memperoleh nilai rata-rata 64,8 dan 74,7 .

3. Penerapan model Talking Stick dapat meningkatkan hasil belajar siswa kelas V SDN 01 Randuagung pada mata pelajaran IPS. Siswa yang mendapat kriteria tuntas belajar berturutturut dari siklus I pertemuan 1 sampai siklus II pertemuan 2 sebanyak 17 siswa atau $63 \%$, 20 siswa atau 74\%, 22 siswa atau 81,4\%, dan 25 siswa atau 92,5\%. 


\section{DAFTAR PUSTAKA}

Achmad, Arief. 2005. Pembelajaran Pendidikan IPS di Sekolah Dasar, (Online), (http://researchengines.com/0805arief7.html), diakses 8 Februari 2011.

Akbar, Sa'dun. 2010. Penelitian Tindakan Kelas. Malang: Cipta Media Aksara.

Arikunto, Suharsimi. 2003. Dasar-Dasar Evaluasi Pendidikan (Edisi Revisi).

Jakarta: Bumi Aksara.

Arikunto, Suharsimi. 2009. Penelitian Tindakan Kelas. Jakarta: Rineka Cipta.

Darlia, Tatik. 2010. Penerapan Model Talking Stick Untuk Meningkatkan Hasil Belajar IPS Pada Siswa Kelas V SDN Blitar Kota Blitar. Skripsi tidak diterbitkan. Malang: FIP UM.

Dimyati dan Mudjiono. 2006. Belajar dan Pembelajaran. Jakarta: Rineka Cipta.

Djamarah, 2005. Guru dan Anak Didik dalam Interaksi Edukatif suatu Pendekatan Teoritis Psikologis. Jakarta:Rineka Cipta.

Djamarah, 2008. Psikologi Belajar. Jakarta:Rineka cipta.

Fathurrohman, Pupuh. 2009. Strategi Belajar Mengajar: Melalui Konsep Umum dan Konsep Islami. Bandung: Refika Aditama.

Hamalik, Oemar, 2010. Proses Belajar Mengajar. Jakarta: Bumi Aksara.

Hidayati, dkk. 2009. Pengembangan IPS SD. Jakarta: Derektorat Jenderal Pendidikan. Pendidikan Nasional.

Ibrahim, R \& Nana, Syaodih. 2010. Perencanaan Pengajaran. Jakarta: Rineka Cipta.

Isjoni. 2010. Cooperative Learning, Efektifitas Belajar Kelompok. Pekan Baru: Alfabeta.

Mashudi, Toha. 2009. Strategi Belajar Mengajar IPS. Malang: Universitas Negeri Malang.

Mulyasa, E. 2010. Kurikulum Tingkat Satuan Pendidikan. Bandung: PT. Remaja Rosdakarya.

Peraturan Menteri Pendidikan Nasional Republik Indonesia Nomor 22 Tahun 2006 Tentang

Standar Isi Untuk Satuan Pendidikan Dasar dan Menengah. 2010. Malang: KKPS

Dinas Pendidikan Kabupaten Malang.

Peraturan Menteri Pendidikan Nasional Republik Indonesia Nomor 41 Tahun 2007 Tentang Standar Proses Untuk Satuan Pendidikan Dasar dan Menengah. 2010. Malang: KKPS Dinas Pendidikan Kabupaten Malang.

Poerwadarminta, WJS. 2003. Kamus Umum Bahasa Indonesia. Jakarta: Balai Pustaka.

Ramadhan, Tarmizi. 2010. Talking Stick, (Online), (http://tarmizi.wordpress.com/2010/02/15/talking-stick/), diakses 8 Februari 2011.

Riyanto, Yatim. 2009. Paradigma Baru Pembelajaran. Jakarta: Prenada Media Group

Ruminiati, 2008. Pengembangan Pendidikan Kewarganegaraan SD, Malang: Universitas Negeri Malang.

Sapriya. 2009. Pendidikan IPS Konsep dan Pembelajaran. Bandung: PT Remaja Rosda Karya. Sardiman. 2004. Interaksi dan Motivasi Belajar Mengajar. Jakarta: PT Raja Grafindo Persada.

Sudijono, Anas. 2008. Pengantar Statistik Pendidikan. Jakarta: Raja Grafindo

Persada.

Suherman. 2008. Metode Pembelajaran Talking Stick, (Online), (http://gurulia. Wordpress.com), diakses 8 Februari 2011.

Sumantri, Mulyani. 2008. Perkembangan Peserta Didik. Jakarta: Universitas Terbuka.

Suprijono, Agus. 2009. Cooperstive Learning , Teori Dan Aplikasi PAKEM. Surabaya: Pustaka Pelajar Jogjakarta.

Sutama, Wayan, I. 2010. Pengembangan Pembelajaran Anak Usia Dini. Dalam Imam Suyitno (Ed), Handbook of Life Skills Development. Malang: LPM UM.

Syah, Muhibbin. 2010. Psikologi Pendidikan dengan Pendekatan Baru. Bandung: PT Remaja Rosda Karya.

Undang-Undang Republik Indonesia Nomor 20 Tahun 2003 Tentang Sistem Pendidikan Nasional. 2010. Malang: KKPS Dinas Pendidikan Kabupaten Malang.

Wahyudin, Dinn. 2008. Pengantar Pendidikan. Jakarta: Universitas Terbuka. 
AL-ADZKA, Jurnal Ilmiah Pendidikan Guru Madrasah Ibtidaiyah

Volume VIII, Nomor 01, Hal (17-31)

Juni 2018 